\title{
Challenging Issues Facing the Professionals of Child Protection in Estonia, Finland, Slovenia and Spain: A Comparative Study
}

\author{
Sandra Martínez-Molina \\ Polibienestar Research Institute (University of Valencia) \\ Jorge Garcés Ferrer \\ Prince of Asturias Distinguished Visiting Professor at Georgetown University, Polibienestar Research Institute (University \\ of Valencia) \\ Barbara Haage, Mari-Liis Mänd \\ NGO Estonian Advice Centre \\ Špela Reš, Petra Belina, Boris Veler \\ Nora Institute Slovenia \\ Elina Järvenpää, Eeva Määttänen \\ Finnish Rape Crisis Centre Tukinainen
}

Acknowledgement ${ }^{1}$

Abstract

Child maltreatment is a phenomenon which has a high impact on child health, causing serious disruptions in the development of the child and, in some extreme cases, their death. Thereby, cooperation and coordination among services and professionals is a crucial factor affecting the effective assistance of children who have been victims or witnesses of violence. However, the intervention in cases of child maltreatment is a complex issue that faces specific difficulties in every step of the intervention process which also may depend on each country's features and its protection system. Specifically, this paper is focused on the most challenging issues that different professionals of child protection services, such as social workers, health-care specialists and psychologists among others, face in Estonia, Finland, Slovenia and Spain, with particular emphasis in professional's training needs. A methodological triangulation, combining desk research, focus groups and questionnaires have been used to obtain a broader and deeper perspective of the objective of the study. The analysis developed in this paper has shown that coordination among professionals and system, legal procedures, attitudes, training issues and lack of resources can be understood as the main challenges that professionals have to face. As for professionals' training needs, the results have shown that they were different in each country. This fact might be related to idiosyncratic features and configuration of the child protection systems and the kind of potential users that they have.

Keywords: child protection, child maltreatment, professional's challenges, training needs

\section{INTRODUCTION}

${ }^{1}$ The findings obtained in this paper are part of the project entitled "Support services for child victims of v iolence in Estonia, Finland, Slovenia and Spain" (JUST/2014/RDAP/AG/VICT/7469) funded under the Rights, Equality and Citizenship Programme (REC

Programme) and the Justice Programme of the European Commission. 
Child maltreatment by definition encompasses various types of abuse, physical, sexual and physiological abuse, as well as neglect and exploitation of children or young people; it is a phenomenon which has a severe impact on the child's health, causing serious disruptions in the development of the child and, in some extreme cases, can lead to death. The intervention process in these cases is a complex issue that can face specific challenges depending on the type of abuse, intervention procedure, characteristics and protection system of a country. As children face difficulties when it comes to reporting violent acts committed against them, the role of professionals working in this field is crucial. Therefore, professionals working on any such case must be able to identify different kinds of child maltreatment and act according to each particular case of abuse and circumstance. In this situation, the cooperation and coordination among services and professionals, as well as their skills, are key factors affecting the prevention and the effective assistance of children who have been victims or have witnessed violence.

Given this premise, the principal aim of this paper is to identify the most challenging issues and difficulties faced by professionals involved in child protection (by professionals we refer to social workers, health-care specialists and psychologists amongst others) in Estonia, Finland, Slovenia and Spain. Specifically, particular attention has been paid to professionals training needs as a key aspect in the process of assisting and supporting children who have fallen victim to violence or who have witnessed violence. To this end, a case study in the above mentioned countries has been developed by combining desk research and existing sources of information in order to determine the training requirements that should be provided to individuals involved in child protection services.

This paper is divided into four main sections. The first section, the "Theoretical Framework" presents a general overview of child maltreatment in the aforementioned countries, with a special attention to the network of professionals and services that assist in situations of child abuse, and the main difficulties they face in each country. The second section "Methodological issues" describes the methodology used in this study. "The "Results" section, gathers the main findings obtained in each country regarding professionals training needs. Finally, the last section provides a summary of the main conclusions and ideas reached in this paper.

\section{THEORETICAL FRAMEWORK}

This section analyses and compares the child maltreatment phenomenon among the countries studied, paying special attention to the main available resources when dealing with these cases. Furthermore, this section offers an analysis of the main problems that professionals working in this field have to face.

\subsection{An overview of child maltreatment in Estonia, Finland, Slovenia and Spain}

Child maltreatment is a phenomenon which can severely impact on the child's health, causing serious disruptions in the development of the child and, in some extreme cases, their death. The intervention procedure in these cases is a complex issue due to the fact that the driven factors and prevention strategies differ depending on victim's age, the environment where such violence occurs and the relationship between the victim and the abuser (WHO, 2009). In addition, intervention faces specific difficulties in every step of the process which also may depend on each country's characteristics and protection system.

In tackling this issue, an important first step is to delimitate what we consider to be child maltreatment. Although there are several ways to classify child maltreatment, depending on several variables such as the moment, authors, kind of action and its intensity (Spanish Childhood Observatory, 2006; The Spanish Ministry of Health, Social Services and Equality, 2014), according to WHO (1999) four kinds of child abuse stand out: physical, emotional and psychological, sexual abuse and negligence. Beyond these four types of abuse, a child being witness to domestic violence has also been regarded as abuse, or considered a kind of psychological maltreatment (The Spanish Ministry of Health, Social Policy and Equality, 2011).

Although cases of child abuse can take place in various contexts, many of them occur in the family or within the home, with parents being the main aggressors (Pinheiro, 2006). This fact shows the worrying relevance of violence within the family, which has also been evidenced in the case countries in this study. For example, in Slovenia every year 300 suspicious cases of neglect and abuse are reported to the police together with around 150 cases of sexual assault against a person under 15 years old. Thus, Slovenian social work centres mainly deal with cases of domestic violence, in which children 
have suffered neglect or some kind of psychological physical or sexual abuse. In Finland, due to the sociodemographic characteristics of the Finnish population, immigrant minors deserve important attention since they come from a wide range of backgrounds such as immigrant families, refugees, asylum seekers or illegal immigrants. Within this collective, maltreatment is mostly related to domestic violence or related to cultural background under the so-called harmful traditions. In Spain, according to Save the Children (2015), twelve children were killed due to domestic violence from 2013 to 2015. Studies have also shown that fathers are the main aggressors in cases of physical, psychological, and sex ual abuse while mothers are the main aggressors in negligence cases (Ministry of Health, Social Services and Equality, 2014).

Despite the alarming prevalence of violence against children within families, it is considered that official statistics might only be the tip of the iceberg as a result of the difficulty in identifying the real number of child maltreatment cases. Beyond limitations such as the scarcity of available data, child maltreatment detection is particularly difficult due to several factors such as fear of reporting abuse, the difficulties that children must overcome when reporting violent acts, and the "social acceptance" of some kind of said violence (Pinheiro, 2006; Save the Children, 2015; Spanish Childhood Observatory, 2006). Along with this, some child maltreatment forms, such as psychological abuse, could be more difficult to detect (Arruabarrena, 2011; Spanish Childhood Observatory, 2006). Consequently, prevention, detection and effective assistance to children who have been victims or witnessed violence requires skilled specialists and the cooperation and coordination among services and professionals working in this field, so that integral attention to these situations can be administrated timely and successfully. The following sections describe the resources available for the protection and prevention of child maltreatment situations in Estonia, Finland, Slovenia and Spain.

\subsection{Resources available for the protection of children against maltreatment, and difficulties faced by the professionals involved in child protection services}

As mentioned before, coordination and cooperation between professionals as well as services and resources are crucial when it comes to providing an effective integral attention to child maltreatment cases. In this section we describe the main resources available, in the studied countries, to protect children who have been victims of abuse. Special attention has been paid to the most important legal resources available, to the job of professionals working in the child protection field and the coordination among them. Furthermore, this section highlights some of the difficulties encountered in the child protection system by country.

\subsubsection{Legal framework}

Legal framework constitutes an essential tool in the protection and guarantee of children's rights and helps avoid harmful disruptions to their development. Particularly, during the $20^{\text {th }}$ century the protection of children has been a topic considered by public authorities. During this process, an important milestone has been the establishment of the United Nations and the Convention on the Rights of the Child in 1989, inspiring and affecting both national and international legal frameworks in this matter (Alemán, 2014). However, despite the European Union action in protecting children's rights, national legislation in this matter in each country differs, configuring different national systems (Bartolomé, 2013).

In particular, the Slovenian legal framework is trying to build a culture of zero tolerance towards violence against children by prohibiting corporal punishment, at home or by family members. Currently, the Slovenian Criminal Code (KZ-1B, 2011) details criminal offences against the sexual integrity of children including exploitation through prostitution (Article 175) and manufacture, possession and distribution of pornographic material (Article 176). In addition, its last amendment introduced grooming as a crime in Article 173. Besides the Criminal Code (KZ-1B, 2011), the Slovenian legal framework is also made up of some rules adopted by the Slovenian Ministry of Education and Sport and the Slovenian Media Act. Hence, the rules adopted by the Slovenian Ministry of Education and Sport when dealing with domestic violence in the educational field specify ways to assist children who have been victims of abuse, and forms to cooperate with other institutions. In addition, the Slovenian Media Act tries to protect children by requiring that advertisements featuring children should not include scenes of violence, pornography or anything that could damage their health, mental or physical development. In Estonia the last Child Protection Act which entered into force in January, 1st 2016 is the main statute for the protection of children nowadays. Specifically, in section 12 of this Act the Government of the Republic is in charge of approving drafts and national strategies and ensuring enough funding. Also the Violence Prevention Strategy 2015-2010 together with the Child Protection Actmust achieve set objectives in this area. In Finland, the Act on Child Custody and Right of Access (361/1983) prohibits oppressing, physically punishing or subjecting a child to any other form of abusive treatment. The Criminal Code 
of Finland (39/1889) prohibits sexual abuse of and violence against children. The protection of children is defined in the Child Welfare Act (417/2007) and this Act is applied to all children in Finland regardless of their background. Furthermore, this Act establishes the kind of professionals who can work in the child protection field (Article 25) and stresses the duty to report child abuse cases to the police. Specifically, in Finland, municipalities are in charge of child welfare services and social workers are responsible for child welfare in these municipalities. Similarly, in Spain, the Spanish model for child protection is decentralised and organised through the autonomous communities. According to Article 39 of the Spanish Constitution $^{1}$, public powers must provide comprehensive protection to children. As autonomous communities have legal powers to guarantee social assistance, regional governments have developed their own laws on child protection leading to a decentralized structure in the child protection field. Thus, Organic Law 8/2015, 22nd July 2and Law 26/2015, 28th July ${ }^{3}$ modifying the child and adolescent protection system are a reference for the legislative development of the autonomous communities, guaranteeing coordination and a uniform protection over the entire territory. Furthermore, in Spain the national plans such as 2nd Strategic National Plan for Childhood Adolescence (PENIA, 2013-2016) and the Comprehensive Plan for Family Support (PIAF, 2015-2017) constitute a framework of cooperation between administrations and agents, establishing diverse strategic lines to follow, in order to achieve the wellbeing of minors and families.

\subsubsection{Networking: coordination and cooperation between professionals working with child abuse victims.}

Networking has a large role in the timely and effective assistance of children and their families. Generally speaking, the purpose of the network is to solve everyday problems of the person needing assistance and delimit relationships between certain people or groups. Furthermore, networking can be regarded as an opportunity to work effectively by sharing the available information to help those needing assistance in a less painful manner (Korp \& Rääk, 2004). According to Haage (2015), networking is made up of two modalities: the primary and the secondary network. The first one is composed of parents, siblings, relatives, neighbours, and friends whereas the second one consists of various professionals belonging to the network through certain formalized channels.

In particular, the secondary network is especially important when the primary network shrinks back. In other words, when the parents are not able to take care of their children or there is a maltreatment situation, other institutions and professionals have to take part in the process to protect minors (Department of Social Welfare of the Government of Valencia, 2011). On the whole, this secondary network in cases of child maltreatment is made up of professionals belonging to areas such as education, health, social and police services, legal and philanthropic organizations. For example, in Estonia child protection workers, operating in administration of the Social Insurance Board or in local and county governments, play a significant role by performing diverse tasks such as raising awareness in the community, direct work with clients and case management. As mentioned before, in Finland there is a large number of professionals working together to ensure the protection of children. Within the Finnish secondary network, the police service has a crucial role in the detection of cases as, according to Article 25 of Child Welfare Act, professionals and authorities must report any suspicious case of abuse to them. However, child protection workers and social work centres are crucial actors when there is a detected case of child abuse. Similarly, in Slovenia, the secondary network is made up of several professionals and services such as the police, social work centres and centres for children and teenagers, schools, counselling centres for children, teenagers and philanthropic organizations. In particular, among this network, two good practices merit particular attention: the project called "Defender-the voice of a Child" and "TOM telefon". The former consists of a child defender network focused on making sure that children are aware of the most important information concerning their life. The latter, "TOM telefon", provides a helpline to help children and young people on issues such as Internet use, online bullying, sexting and other kinds of online abuse. Likewise, in Spain, professionals from the aforementioned areas are involved in the child protection field in order to provide an integral attention to child abuse situations by playing different roles. Consequently, while the main role of the police, health and education services is more related to the identification of maltreatment cases, social services are responsible for evaluating every situation and carrying out actions to improve the child's situation once a case

\footnotetext{
${ }^{1}$ Constitución Española. Boletín Oficial del Estado, 29 de diciembre de 1978, núm. 311, pp. 29313-29424.

${ }^{2}$ Ley Orgánica 8/2015, de 22 de julio, de modificación del sistema de protección a la infancia y a la adolescencia. Boletín Oficial del Estado, 23 de julio de 2015, núm. 175, pp.61871-61889.

3 Ley $26 / 2015$, de 28 de julio, de modificación del sistema de protección a la infancia y a la adolescencia. Boletín Oficial del Estado, 29 de julio de 2015, núm. 180, pp. 64544-64613
} 
has been detected (Department of Social Welfare of the Government of Valencia, 2010; 2011). In order to coordinate the aforementioned services and professionals, the Spanish Ministry of Health, Social Services and Equality (2014) launched a protocol for action in cases of child maltreatment with the aim of offering general guidelines for the actions that the professionals have to carry out in these cases.

Therefore, the cooperation and coordination of professionals is fundamental since it pinpoints the role of professionals working in these cases by avoiding duplicities in services and improving the effectiveness of the net, offering a multidisciplinary solution to a complex problem. However, the main challenge in child maltreatment cases may be the coordination among professionals and system, reducing the effectiveness of the responses given.

\subsection{Difficulties faced by the professionals involved in child protection services}

As previously mentioned, a case of child maltreatment is a sensitive and complex matter which faces several intrinsic difficulties. In tackling with these cases, professionals have to deal with specific obstacles in every step of the process, together with some difficulties which may depend on the characteristics and legislations of each country's protection system. For example, the impact analysis of the draft Child Protection Act in Estonia and the abused child assistance system highlight the main problems within the Estonian system. First of all, the fact that there is no single organisation responsible for helping abused children in Estonia can be regarded as a factor affecting victims. In this regard, it was noted that victims could end up escaping the notice of different professionals and, consequently, not receiving the right services. In addition, the lack of central coordination and the poor communication among professionals were considered to be limiting, impacting on the potential re-victimization of children who may end up talking about their case to various specialists. Firstly, although supervision was regarded key point in this analysis, it was argued that the supervision system of child protector workers had not been consistently developed, not being available to everyone. Secondly, some challenges detected in Estonia were related to training and professional development. Thus, after Estonia regained its independence in 1990 training and teaching of social workers, also child protector workers began in Tallinn University. While many people acquired the needed education, there were many people that did the job without having the right knowledge and education for this specific job. Estonia still faces some challenges related to training and professional development. There are still child protector workers working in the social work field without having the necessary education for the job and thus, professionals may use different methods and techniques when dealing with child maltreatment cases. A big step forward to change the problem has been made in Estonia. According to Section 19 of the Child Protection Act, which came into force in 2016, a child protection worker should have professional training and higher education. Therefore, child protection workers who do not have the needed education should have it in two years. Together with this, the Estonian certification system, more focused on professional certificates and theoretical knowledge than on experiences and additional training, was considered another limitation, as real cases go further than theoretical knowledge. Thirdly, the shortage of child protection workers was noted as a constraint, making access to services more difficult. As a result, more attention may be paid to consequences rather than prevention in the intervention of child maltreatment cases. Finally, public attitude was considered as an important factor when it comes to reporting abuse cases, affecting the professional's ability to recognize and offer intervention to a possible case of child abuse (Salla, Surva, Ilves, Soo \& Reinomägi, 2013). According to the aforementioned analysis, public attitudes are relevant since little attention is paid to supporting parenthood and to returning children to their biological families in the future. Further than these limitations, a study developed by Soo, llves and Strömpl (2009) showed that professionals had different awareness of the existence of laws, regulations and other guidelines related to providing assistance to an abused child in Estonia. Similarly, in Slovenia the lack of resources, human, economic or logistic, such as specific programs and training for professionals, seems to be an important issue. In addition, coordination among professionals and lack of recognition of modern forms of aggression as well the difference between law and practice, are considered challenges that professionals working in child protection field face in Slovenia. In this respect, in Finland, some specific difficulties are related to legal procedures and the duty to report child abuse cases to the police. Explicitly, the Child Welfare Act in Article 25 establishes that a wide range of professionals from different fields have the duty to notify the municipal body responsible for social services if they discover a case in which it is necessary to open an investigation to monitor and ensure the welfare of a child. However, more information may be needed among professionals about what cases they are obliged to report. Likewise, in Spain, some professional challenges are linked to the detection of child maltreatment cases. This is a very delicate issue, since the real number of child maltreatment cases is unknown, given that most of them are not detected (Save the Children, 2015; Spanish Childhood Observatory, 2006). According to Spanish Childhood Observatory (2006) and the Department of Social Welfare of the Government of Valencia (2010) factors such 
as the lack of a clear definition of child maltreatment, the difficulty in distinguishing child maltreatment from accidental lesions, fear of reporting, poor training of professionals and the lack of confidence in the child protection system may be potential impediments when detecting child abuse cases. Beyond the detection step, the intervention process in Spain also presents several challenges. Specifically, professionals face difficulties caused by the lack of involvement of the family, the balance between interventions based on helping and controlling the family, and the various differences in ethnic and cultural lifestyles (Basells, 2006) Furthermore, lack of resources and prevention programmes needed to cope with child maltreatment cases are also highlighted as factors hindering child protection in the Spanish legislation context (Trenado, Pons-Salvador \& Cerezo, 2009).

Therefore, although different challenges have been identified in each country, detection is a common sensitive issue in every place, due to some factors such as public attitudes or cultural aspects, the difficulty in identifying some kind of abuses, the fear of reporting them and the lack of knowledge or specific training. Moreover, the lack of coordination within the system, insufficient human and economic resources, as well as inadequate training of social workers can be considered common difficulties in child protection services by literature. Specifically, some of the main shared obstacles in the countries studied have clearly been poor knowledge and insufficient skills of professionals working in this field in respect to several matters. As mentioned above, effective assistance of children who have been victims or witnessed violence requires intervention by skilled professionals, who must be able to identify and deal effectively with different kinds of child maltreatment Consequently, this paper pays particular attention to professional's training needs as a key aspect in the process of assisting and supporting children who have fallen victim to violence or who have witnessed violence, in Estonia, Finland, Slovenia and Spain, as a way of improving the ability and capacity to provide assistance to children affected, by professionals working in this field.

\section{METHODOLOGICAL ISSUES}

As mentioned before, the main aim of this report is to identify social workers training needs in Estonia, Finland, Slovenia and Spain. Specifically, this section describes the methodology and instruments used in each country in order to gather information about the potential training needs of the professionals working in the field of child protection.

\subsection{Methodological issues in Estonia}

In order to map the professional's training needs of child protection workers and psychological counsellors in Estonia, desk research and a content analysis of some relevant reports dealing with this topic was developed. Specifically, the following documents were analysed:

Table 1: Documents analysed in Estonia

Abused child assistance system, Karu (2015)

Training needs assessment analysis of child protection officials, The National Institute for Health Dev elopment (2015)

The training plan for the basic training of child protection officials, The National Institute for Health Development (2015)

The need for training and occupational counselling for psychologists providing psychological counselling services, the Ministry of

Justice (2015)

Summary of the impact analysis of the draft Child Protection Act, CASS University of Tartu (2013)

\subsection{Methodological issues in Finland}

In Finland they used the questionnaire 1 technique in order to find out the professional's training needs. The questionnaire was made up of 6 questions, combined with the Likert scale, to gather quantitative data, and open-ended questions to gather qualitative data. This questionnaire was handed over to specialists working in different fields at national level.

\footnotetext{
${ }^{1}$ More details about the questionnaire are show $n$ in the annex
} 
The answers received came from communal social and health-care specialists and specialists working in philanthropic organizations and private sector. The total amount of answers received was $95(\mathrm{~N}=95)$. Precisely, the composition of the sample was made up of different professionals as Table 2 shows:

Table 2: Finland composition sample

$77 \%$ of professionals from communal social or health-care

$15 \%$ of professionals from association or organisation

$4 \%$ of professionals from private sector

$4 \%$ Other professionals

\subsection{Methodological issues in Slovenia}

In Slovenia they analysed the professional's training needs through several techniques and methods. In detail the techniques and methods applied were the following:

- Desk research: based on the analysis of web sources such as programs and portals to help child abuse victims and web sources of legislation, regulation and strategies.

- Statistical analysis: analysis of criminal acts reported to the police in Slovenia on victims under 18 years old.

- Interviews $1: 19$ structured interviews with 22 questions were conducted $(\mathrm{N}=19)$. The interview covered the following topics: basic information; statistics; forms of help and competences. Interviewees were different specialists working on cases of children victims of violence. Specifically, these professionals belonged to fields and organizations shown in Table 3:

Table 3: Sample of Slovenian centres

Social Work Centres

Juv enile Centres and Residential Groups for Children and Youth

Human right Ombudsman-"defender-The Voice Of A Child" Project

Tom Telefon-Helpline For Children And Youth In Need

Safe Houses For Abused Women And Children

Safe.si And Spletno Oko (w eb eye)- Centre For Safe Use of the Internet

Police/Criminal Police Directorate- Homicide and Sexual Offences Section (child sexualabuse department)

Judges in Family Courts

Primary School-school Counsellors

\subsection{Methodological issues in Spain}

In order to obtain qualitative information, such as the kind of training needed by professionals working in child protection field, the "focus group" technique was applied in Spain. Specifically, the Spanish focus group was made up of eight professionals with the aim to gather several opinions about this topic. According to the criteria of homogeneity and heterogeneity (Canales \& Peinado, 1995), social field professionals and philanthropic organizations were invited. In detail, the profiles of the professionals were the following:

Table 4: Spanish focus group professionals' profiles

Two social workers from municipal social services

A psy chologist from family, minors, and youth Section from a local administration

A psy chologist from a philanthropic organzation

A social w orker from a philanthropic organization

\footnotetext{
${ }^{1}$ The ex tract of the interview is shown in the annex.
} 
A psy chologist from a centre for minors

A social w orker working in a hospital

A regional manager of a philanthropic organization

The session of the focus group in Spain was developed and structured according to Llopis (2004) instructions ${ }^{1}$.

\section{RESULTS FROM THE ANALYSIS}

This section presents the results obtained in the countries studied regarding the professionals' training needs in Estonia, Finland, Slovenia and Spain.

In Estonia, desk research has shown that there is room for improvement in training needs among psychologists and child protector workers. Firstly, regarding psychologists, the analysis has shown that they feel the need for continuing their education in almost all areas of counselling. On the basis of the literature reviewed, the following necessary training topics have been exposed among psychologists: trauma work, complex trauma stabilization, therapy workshops, specific topics (e.g. bodily injuries, domestic violence and parents with a personality disorder, a child caught in the divorce process, the psychological self-help techniques, family violence, protracted grief, and motivation) and legislations to protect victims. Secondly, regarding the training needs of child protection workers, according to a study conducted by TAI (2015a; 2015b), $90 \%$ of them expressed the need for further training. In this study, some topics requiring additional training were mapped out. Among them, some important topics were stressed, such as recognizing an abused child and working with families, case management, child welfare assessment framework, means of primary level assessment, motivational interview, networking seminars, forms of conciliation and several aspects related to the legal framework.

The results in Finland showed three main areas in which professionals would rather have a deeper knowledge. First of all, over $80 \%$ of professionals felt that they needed more training concerning psychological information about traumas. Specifically, workers in this field stressed the necessity for information about traumas and how to reach children who have been abused or have witnessed violence, or could become victims. Secondly, almost $80 \%$ of the interviewees expressed the need for extra training regarding sexual abuse and dealing with victims of foreign backgrounds. Given that a specific group of victims are children of immigrants, $85 \%$ of the interviewees said that they would welcome more training regarding this topic, also because of the increase in number of refugees in Finland and their difficulty to understand the Finnish system of protection. Thirdly, legislation was a sensitive topic as half of the interviewees reported that they would require more training about cases in which there is a need to notify the police. Indeed, according to the results, many of the social and health-care specialists did not mention their duty to notify the police when there was a case of child maltreatment. Finally, as for the types of training, $59 \%$ of the respondents preferred face to face training to online training. Moreover, some interviewees specified that training based on group conversations would give new perspectives and ideas on how to best deal with child maltreatment cases.

In Slovenia several professional' training needs have been identified by different centres where professionals were interviewed. Although some of them varied depending on centres or the sort of services, Slovenian results have shown some common areas in which professionals have expressed the necessity of in depth knowledge. Areas identified include topics such as training on how to recognise different forms of violence, such as online violence, children's needs, how to communicate with children and how to provide help to child abuse victims.

In Spain, the content analysis of the Spanish focus group mainly discussed the type of training needed and also what kind of content it should have. As for the first aspect, the professionals showed a preference for practical training. In this regard, they stressed the need to have time for reflection in order to share proposals and experiences that may contribute to knowledge exchange. Consequently, they proposed, as a useful type of training, seminaries or direct monitoring of cases by other professionals in order to offer opinion or advice. The second main point they discussed focused on addressing the potential training topics. The content analysis showed the following important subjects for consideration: the

${ }^{1}$ The structure of the focus group session is shown in the annex 
methodology for intervention, interviewing skills and the management of emotional involvement when dealing with cases of abuse. Therefore the main conclusions reached in the Spanish focus group was the consensus of the necessity of a practical training course, based on the professional expertise of specialists, and the exchange of knowledge focused on methodological aspects related to the intervention in cases of maltreatment

The following Table 5 summarizes the main professional' needs identified in each country studied:

Table 5: Results: potential professionals' training needs by country. Summary table

\begin{tabular}{|c|c|}
\hline Country & Results main professionals training needs \\
\hline Estonia & $\begin{array}{l}\text { Trauma w ork } \\
\text { Complex trauma stabilization } \\
\text { Therapy workshops } \\
\text { Legislation } \\
\text { Psy chological self-help techniques and family violence } \\
\text { Legislation } \\
\text { Recognizing an abusedchild and work with families } \\
\text { Case management } \\
\text { Child welfare assessment framework } \\
\text { Motiv ational interv iew } \\
\text { Netw orking seminars } \\
\text { Forms of conciliation }\end{array}$ \\
\hline Finland & $\begin{array}{l}\text { Psychological information about traumas } \\
\text { Sex ual abuse and victims of foreign background } \\
\text { Legislation } \\
\text { Face to face training }\end{array}$ \\
\hline Slovenia & $\begin{array}{l}\text { Forms of violence and, specifically, online forms of violence } \\
\text { Training focused on providing help to child abuse victims } \\
\text { Children' needs } \\
\text { Communication with children }\end{array}$ \\
\hline Spain & $\begin{array}{l}\text { A need of a practical training course based on professional expertise and knowledge exchange related to the } \\
\text { interv ention in cases }\end{array}$ \\
\hline
\end{tabular}

\section{CONCLUSIONS}

Child maltreatment is a phenomenon which has a traumatic impact on all aspects of a child's life, causing serious disruptions to their development. Although physical, psychological, sexual abuse and neglect are the most common forms of violence against children, new forms, such as use of apps and the Internet, are starting to appear. In addition, being witness to domestic violence has also been regarded as a recognisable form of child abuse or considered as psychological maltreatment (The Spanish Ministry of Health, Social Policy and Equality, 2011). In order to provide an integral attention, professionals from different areas must work together; they should be able to share cooperation and coordination with services and other piers, as this would prove to be a crucial factor in providing effective assistance to children. Usually, specialists from the education sector, health care, civil and police services, legal and philanthropic organizations are involved in the child protection field. However, the intervention process in cases of child abuse is a sensitive issue that faces specific difficulties depending on several variables, such us the type of abuse, steps taken for intervention procedures and country's characteristics and protection system. In this situation, the cooperation and coordination among services and professionals, as well as their skills, are key factors affecting the prevention and the effective assistance of abused children. Specifically, the role played by professionals working in this field is crucial, they must be able to identify and cope with different kinds of abuse and equally diverse cases of child maltreatment.

Given this situation, the purpose of this paper has been to identify the most challenging issues and difficulties for the professional workers involved in child protection services in Estonia, Finland, Slovenia and Spain; It is known from previous literature that training of professionals is a real challenge that exists in these countries (Childhood Observatory, 2006; the Department of Social Welfare of the Government of Valencia, 2010). 
In order to fully explore the professionals' training needs in these countries, a case study has been developed by combining desk research and primary sources of information. The results have shown that in each country, professionals needs have been different. These findings might be related to idiosyncratic features and configuration of the child protection system in each country and also due to the kind of potential users that they have. For example, results in Estonia have shown that the main training needs of professionals are linked to trauma work and psychological and intervention techniques, further development of skills for recognising an abused child, networking and legislation. In Finland, the results obtained have shown that particular attention should be paid to child sexual abuse victims, especially so on children of immigrants, psychological information about traumas and legislation and criminal proceedings. Thus, probably because of the demographic characteristics of the people in Finland, and the increase in refugees, multicultural aspects will require more attention in the future. Besides, legislation and criminal proceedings were also stressed among Finnish training needs. This knowledge is important as it might give the victims better access to their rights and encourage professionals to report abuse cases to the authorities. The research work developed in Slovenia has shown that recognizing forms of violence in general and, especially, new forms of abuse through online channels has been a potential topic of additional training for professionals. They also expressed a clear need of training focused on providing assistance to child abuse victims. Lack of training in this particular area might cause the reduction of direct work and counselling in cases of child abuse in some organizations such as social centres, schools, youth centres and philanthropic organizations. Finally, in Spain the results obtained through the focus group have shown that training courses usually do not take into account the challenges and difficulties professional workers face in real cases of abuse, as they are divorced from social reality. For this reason, they stressed the need of a practical training course based on professional expertise and knowledge exchange related to the intervention in cases of child maltreatment.

In conclusion, the present research paper has contributed positively in broadening and exposing awareness over the training needs of professional workers in Estonia, Finland, Slovenia and Spain, stressing the role played by professionals in cases of child maltreatment. It is considered that results reached in this study show a significant insight into the necessity to reinforce the abilities and resources available to professionals working with these sensitive cases, in an effort to increase the effective and timely assistance of children who have been victims or have witnessed violence.

\section{REFERENCES}

[1] Alemán, C. (2014). Políticas públicas y marco de protección jurídica del menor en España. UNED. Revista de Derecho Político, 90, 97-134.

[2] Arruabarrena, M. I. (2011). Maltrato psicológico a los niños, niñas y adolescentes en la familia: definición y valoración de su gravedad. Psychosocial Intervention, 20, 25-44.

[3] Balsells, M.A. (2006). Québec y Cataluña: redes y profesionales para la acción socioeducativa con familias, infancia y adolescencia en situación de riesgo social. Revista Española de Educación Comparada, 12, 365387.

[4] Bartolomé, J.C. (2013). La poliédrica y heterogénea protección internacional de los menores. Revista sobre la infancia y la adolescencia, 4, 1-27. DOI: http://dx.doi.org/10.4995/reinad.2013.1462.

[5] Canales, M., \& Peinado, A. (1995). "Grupos de discusión". En Delgado, J.M. y Gutiérrez, J. (coord.): Métodos y técnicas cualitativas de investigación en ciencias sociales. Madrid: Editorial Síntesis, p. $287-316$.

[6] Department of Social Welfare of the Government of Valencia (2010). El papel del ámbito policial en la detección y abordaje de las situaciones de desprotección o maltrato infantil. Valencia: Generalitat Valenciana.

[7] Department of Social Welfare of the Government of Valencia (2011). El papel del ámbito de los Servicios Sociales en la detección y abordaje de las situaciones de desprotección o maltrato infantil. Valencia: Generalitat Valenciana.

[8] Estonian Ministry of Justice (2015). The need for training and occupational counseling for psychologists providing psychological counseling service. Retrieved from: http://www.kriminaalpoliitika.ee/sites/krimipolitika/files/elfinder/dokumendid/psuhh._noustajate_toonoustamisja_koolitusvajadus.pdf 
[9] Estonian Ministry of Social Affairs (2015). Violence Prevention Strategy (2015-2020). Retrieved from: http://www.kriminaalpoliitika.ee/sites/www.kriminaalpoliitika.ee/files/el finder/dokumendid/ves_2015-2020_1.pdf

[10] Estonian National Institute for Health Development (TAI) (2015a). Training needs assessment analysis of child protection officials. Retrieved from:

https://intra.tai.ee/images/prints/documents/144014866389_Lastekaitset66tajate_koolitusvajaduse_analyys_k okkuv6te.pdf

[11] Estonian National Institute for Health Development (TAI) (2015b). The training plan for the basic training of child protection officials. Retrieved from: http://www.tai.ee/images/PDF/Lastekaits etootajate_koolituskava.pdf

[12] Haage, B. (2015) Lasteaedade ja kohaliku omavalitsuse koostöö Nõmme linnaosa näitel: abivajavast lapsest teavitamine. Tallinna Ülikool

[13] Karu, J. (2015). Poliitkaanalüüs - Väärkoheldud lapse abistamise süsteem [Policy Analysis - the Assistance System of an Abused Child]. Tallinn: Ministry of Social Affairs.

[14] Korp, E., \& Rääk, R. (2004). Child Protection Work in Local Government. Tallinn: National Institute for Health Development. Retrieved from: http://www.eat.ee/wp/wpcontent/uploads/Las tekaitsetoeoetaja_20kasiraamat.pdf

[15] Llopis, R. (2004). El grupo de discusión: Manual de aplicación a la investigación social, comercial y comunicativa. Madrid: ESIC Editorial.

[16] Pinheiro, P.S. (2006). Prevención del maltrato infantil: Qué hacer, y cómo obtener evidencias. Retrieved from: http://www.unicef.org/violencestudy/spanish/reports/Chapitre\% 2001\% 20\% 20intro.pdf

[17] Salla, J., Surva, L., Ilves, K., Soo, K., \& Reinomägi, A. (2013) Lapse turvalisus. Retrieved from: http://www.lastekaitseliit.ee/wp-content/uploads/2011/04/Laste_heaolu_sisu-1.pdf

[18] Save the Children (2015).Violencia contra la infancia. Hacia una estrategia integral. Retrieved from:htps://www.savethechildren.es/sites/defaultffiles/imce/docs/violencia_contra_la_infanciahacia_una_estrategia_integral_.pdf

[19] Soo, K.; llves, K.; and Strömpl, J. (2009). Notification of cases of child abuse and networking. Tartu: Institute of Sociology and Social Policy of University of Tartu

[20] Spanish Childhood Observatory (2006). La infancia en cifras. Madrid: Ministerio de Trabajo y Asuntos Sociales.

[21] Spanish Ministry of Health, Social Services and Equality (2011). Maltrato infantil en la familia en España. Retrieved from: http://www.observatoriodelainfancia.msssi.gob.es/productos/pdf/malt2011v4_total_100_acces.pdf

[22] Spanish Ministry of Health, Social Services and Equality (2013). II Plan Estratégico Nacional de Infancia y Adolescencia 2013-2016. Retrieved

from:http://www.observatoriodelainfancia.msssi.gob.es/documentos/pdf/IIPLAN_ESTRATEGICO_INFANCIA. pdf en enero de 2015.

[23] Spanish Ministry of Health, Social Services and Equality (2014). Protocolo básico de intervención contra el maltrato infantil en el ámbito familiar. Retrieved

from:http://www.observatoriodelainfancia.msssi.gob.es/productos/pdf/Maltratolnfantil_accesible.pdf

[24] Spanish Ministry of Social Services and Equality (2015).Plan Integral de Apoyoa la Familia PIAF (2015-2017). Retrieved from: http://www.msssi.gob.es/novedades/docs/PIAF-2015-2017.pdf

[25] Trenado, R., Pons-Salvador, G., \& Cerezo, M. A. (2009). Proteger a la infancia: apoyando y asistiendo a las familias. Papeles del Psicólogo, 30(1), 24-32.

[26] University of Tartu (2013). Summary of the impact analysis of the draft Child Protection Act, CASS. Retrieved from: https://www.sm.ee/sites/default/files/contenteditors/Lapsed_ja_pered/lastekaitse_alusanaluus_pwc_2013_27.11_2.pdf 
[27] WHO (1999). Report of the consultation on child abuse prevention, Geneva 29-21 March 1999. Geneva: World Health Organization.

[28] WHO (2009). Prevención del maltrato infantil: Qué hacer, y cómo obtener evidencias. Retrieved from: http://apps.who.int/iris/bits tream/10665/44228/1/9789243594361_spa.pdf

\title{
8. APPENDIXES
}

\subsection{Slovenian extract of interview}

The Slovenian extract of interview was the following:

\author{
BASIC INFORMATION \\ 1. Which organization are you employed in? \\ 2. What position? \\ STATISTICS
}

3. How many cases of child abuse has your organization proceeded in the previous year?

4. How many cases of children, witnessing violence have you handled/proceeded in the previous year?

5. Who most commonly reports cases of child abuse victims? How do they come in contact with you?

6. What is the most common form of child abuse that you encounter?

7. Do you work on cases of online violence? How many have you proceeded in the previous year?

8. Which legal basis (laws, declarations, conventions) do you most often lean on when working with child abuse victims?

FORMS OF HELP/ HELP PROVIDED

9. What programs and forms of help do you provide for child abuse victims?

10. What is the procedure (from the beginning to the end)?

11. How long do the proceedings usually take?

12. What do you believe works well in the proceedings when working with child abuse victims?

13. What do you believe are problems in the proceedings of child abuse victims?

14. How good is your cooperation with other organizations that work on providing help for child abuse victims? Please rate the question on scale of $1-5$ : (1) poor, (2) fair, (3) good, (4) very good and (5) excellent.

15. What are the most common issues / cases / reasons that are covered through collaboration?

16. Which are the organizations you most often collaborate with?

17. Do you collaborate with foreign organizations? If yes, which ones?

COMPETENCE

18. What skills and knowledge, in your opinion a person, working with child abuse victims, needs to have?

19. Which professional seminars on the topic of child abuse (victims) have you attended in the previous year?

20. Which topics do you believe these seminars lack?

21. Which topics, in your opinion, are most important and should be obliged for professionals working in the field of child abuse (victims)?

22. How would you validate professional work with child abuse victims? Please rate the question on scale of 1 -5 : (1) poor, (2) fair, (3) good, (4) very good and (5) excellent

\subsection{Finland questionnaire}

The questionnaire which was administrated in Finland was the following:

1. Where do you work?

2. Have you participated in trainings concerning how to be in contact with a child who has fallen victim of violence or who has witnessed violence?

3. Which helping authorities do you get in contact with when you have received information about a child who has fallen victim of violence or who has witnessed violence?

4. On a scale of 1 to 5 , evaluate how necessary extra training is concerning the following areas (cases where a child has fallen victim of violence or has witnessed violence): 
- a child welfare notification

- a notification to the police

- general information about legislation

- crises and traumas caused by violence

- sensitive treatment of victims

- $\quad$ sexual abuse of children

- child victims of foreign background

5. How would you want trainings to be organised (contact or online trainings)?

6. Comment freely on how to develop trainings concerning children who have fallen victim of violence or has witnessed violence

\subsection{Focus group in Spain}

The session of the focus group in Spain was developed and structured according to Llopis (2004) instructions. Specifically, the session was structured as follows:

1. INTRODUCTION

a. Moderators introduction

b. Introduction institution

c. Objectiv es of the meeting

$$
\text { i. } \quad \text { Topic of the meeting }
$$

d. Confidentiality and recording of the meeting

e. Rules of the meeting

i. Sev eral opinions, consensus is not needed

ii. There is not an absolute truth

iii. Not to interrupt

iv. Honestanswers

2. INTRODUCTIONOF PARTICIPANTS
a. Name
b. Institution
c. Position

3. WARM-UP DISCUSSION (Difficulties in a hypothetical case of child maltreatment)
a. Detection
b. Notification
c. Intervention
d. Professionals coordination

4. FREE DISCUSSION.
a. Skills self-learned

5. TOPICS TO DISCUSS
a. Current training deficiencies
b. Description of courses taken that hav e been helpful
c. Type of future training

\section{OPINIONS TO BE CONSIDERED ("Advice to the President")}

7. CLOSING AND THANKS 